\title{
THE EFFECT OF INCREASED FEMALE SEX HORMONE CONCENTRATION ON MOVEMENT PROPRIOCEPTION
}

\author{
Laura Daniusevičiūtè ${ }^{1}$, Vitas Linonis ${ }^{1}$, Lina Barsienè $^{2}$ \\ Kaunas University of Technology', Kaunas, Lithuania \\ Lithuanian University of Health Sciences, Medical Academy², Kaunas, Lithuania
}

\begin{abstract}
Research background and hypothesis. Over the last years, basic research on the effect of different hormones on tendons and ligaments has been initiated. Regarding oestrogen receptor localization in brain and their interaction with neurotransmitters (Maki et al., 2002; Friden et al., 2003; Farage et al., 2008), we speculate that the increase in the level of female sex hormone concentration will improve the sense of movement.

Research aim was to study the effect of increased female sex hormone concentration on movement proprioception.

Research methods. Subjects were healthy and physically active women $(\mathrm{n}=15)$ with normal menstrual cycle, aged 19-23 years, body weight $-58.2 \pm 6.1 \mathrm{~kg}$, height $-168.4 \pm 5.6 \mathrm{~cm}$ as well as female basketball players $(\mathrm{n}=15)$ with normal menstrual cycle, aged $19-23$ years, body weight $-78.31 \pm 2.81 \mathrm{~kg}$, height $-182.40 \pm 4.71 \mathrm{~cm}$. We performed three experiments with each participant: in follicular phase, ovulation and luteal phase. The samples of $5 \mathrm{ml}$ venom blood were taken to establish the amount of estradio17 $\beta$-estradiol and progesterone concentration. The sense of knee joint position was evaluated using isokinetic dynamometer (System 3; Biodex Medical Systems, Shirley, New York, USA). During a training session, a subject's right leg was flexed at the knee joint and fixed at the angle of $90^{\circ}$. Prior to each test, the researcher demonstrated the target angle of $60^{\circ}$ by stretching subject's leg. In order to train the flexion of the knee joint, a subject's right leg was extended at the knee joint and fixed at the angle of $0^{\circ}$. The researcher demonstrated the target angle of $50^{\circ}$ by flexing subject's leg. The subjects had to perform three tests at the velocity of $2 \%, 5 \%$ and $10 \%$ with their eyes open and closed.

Research results. Females in the control group performed knee joint proprioception task better with an extended knee at velocity of $2 \%$ s with open eyes during the follicular phase, but at the velocity of $10 \%$ s the values were better during ovulation. Basketball players performed the same task better at velocity of $5 \% \mathrm{~s}$ during ovulation, but at velocity of $10^{\circ} / \mathrm{s}$ the values were better during the luteal phase. Females in control group performed knee joint proprioception task with an extended knee at the velocity of $5 \% \mathrm{~s}$ with closed eyes better during the luteal phase. No statistical difference between control group and basketball player indices of knee joint position proprioception task with a flexed knee at velocity of $2 \% \mathrm{~s}, 5 \% \mathrm{~s}$ and $10 \%$ with closed eyes during the menstrual cycle was found.

Discussion and conclusion. Knee joint proprioception indices were better during ovulation phase in control group and basketball players.
\end{abstract}

Keywords: knee joint proprioception, follicular phase, ovulation, luteal phase.

\section{INTRODUCTION}

$\mathrm{P}$ roprioception is related to the senses of position and movement of limbs. These senses are mediated through neural input from peripheral mechanoreceptors in the skin, muscles, tendons, ligaments and joint capsules (Friden et al., 2003). Over the last years, basic research on the effect of different hormones on tendons and ligaments has been initiated. Estrogen and progesterone receptors have been indentified on fibroblasts in the humans (Nakata et al., 2010). Estrogen has been shown to decrease the proliferation of fibroblasts and the synthesis of Type 1 procologen (Nakata 
et al., 2010). Previous studies have suggested that the variation of estradiol and progesterone during the menstrual cycle influences neurological and motor functions (Osterlund et al., 2001). Increased levels of progesterone metabolites during the luteal phase are known to affect various transmitters and hormone systems, for example in the cerebellum, resulting in effects on motor functions (Shen Yin-Chen, Franz, 2005). It was ascertained that oestrogen receptors (ER $\beta)$ detected in cerebellum interact with neurotransmitter $\gamma$-aminobutyric acid (GABA) (Friden et al., 2003) and higher estradiol concentration improve procedural memory (Gur et al., 2000). However, the performance of right movements, movement coordination, and balance during ovulation are worse when comparing the indices during follicular and luteal phases (Friden et al., 2003). Several investigations have studied the relationship between menstrual cycle phase and the risk of anterior cruciate ligament (ACL) injuries. There are multiple indications that ACL laxity (Friden et al., 2003), neuromuscular factors (Friden et al., 2006), as well as athletic performance (Shen Yin-Chen, Franz, 2005), may fluctuate during the menstrual cycle. However, these findings have been equivocal and there is little consensus in research literature. Some studies suggested that pre-menstrual and menstrual symptoms affect the athletic performance and neuromuscular control, and may increase the risk of musculoskeletal injuries (Shultz et al., 2005). However, few studies have investigated the influences of these dysfunctions on noncontact ACL injuries (Eiling et al., 2007). The implications of these physiological changes during the menstrual cycle on ACL injury risk in female athletes have not been clarified yet. Regarding oestrogen receptor localization in brain and their interaction with neurotransmitters (Maki et al., 2002; Friden et al., 2003; Farage et al., 2008), we speculate that the increase in the level of female sex hormone concentration will improve the sense of movement. The aim of the study was to study the effect of increased female sex hormone concentration on movement proprioception.

\section{RESEARCH METHODS}

Subjects were healthy and physically active women $(\mathrm{n}=15)$ with normal menstrual cycle, aged 19-23 years, body weight $-58.2 \pm 6.1 \mathrm{~kg}$, height $-168.4 \pm 5.6 \mathrm{~cm}$ as well as female basketball players $(n=15)$ with normal menstrual cycle, aged $19-23$ years, body weight $-78.31 \pm 2.81 \mathrm{~kg}$, height $-182.40 \pm 4.71 \mathrm{~cm}$. The healthy and physical active women $(n=15)$ were chosen as control group. All the participants had not been using oral contraceptives for six months and had regular (28 days) menstrual cycle. Ethical approval was obtained from Kaunas Regional Ethics Committee of Biomedical Research (report number BE-224). Written informed consent was obtained from the volunteers prior to their participation in this study. All the volunteers could be considered as physically active as they took part in recreational activities two or three times per week.

Estimation of basal body temperature. Basal body temperature (BBT) estimation is a method for identifying the approximate day of ovulation, and thus the relative length of follicular and luteal phases (Bauman, 1981). Each subject measured BBT every morning for three months before the experiment. BBT increased approximately by $0.3^{\circ} \mathrm{C}$ after ovulation, which sustained throughout the luteal phase. Using BBT method we chose subjects in the study on their early-follicular phase, when oestrogen and progesterone concentrations were low, and on ovulation, when estrogen concentrations were high (Bauman, 1981).

Estimation of estrogen concentrations. At the beginning of every study, $5 \mathrm{ml}$ of venous blood sample was taken to establish estradiol (17 $\beta$-estradiol) and progesterone concentration in blood. The enzyme immunoassay analysis ECLIA was used to establish estradiol (17ß-estradiol) and progesterone concentration in blood in vitro with Roche Elecsys 1010/2010 cobas e 411 (Roche Diagnostics GmbH, Germany) and Modular Analytics E170 immunological analyzers (Roche Diagnostics GmbH, Germany). In our study we measured estradio17 $\beta$-estradiol and progeterone concentration in blood on the second (follicular phase), fourteenth (ovulation) and twenty third day (luteal phase) of menstrual cycle.

Estimation of knee joint position sense. Knee joint position sense was evaluated using isokinetic dynamometer (System 3; Biodex Medical Systems, Shirley, New York, USA). During a training session, a subject's right leg was flexed at the knee joint and fixed at the angle of $90^{\circ}$. Prior to each test, the researcher demonstrated the target angle of $60^{\circ}$ by extending subject's leg. A subject's right leg was extended at the knee joint and fixed at the angle 
of $0^{\circ}$. The researcher demonstrated the target angle of $50^{\circ}$ by flexing subject's leg (Figures $1 \mathrm{~A}, \mathrm{~B}$ ). The same sequence of actions was used throughout the research while performing the test of the knee joint position sense. The subjects had to perform three tests at the velocity of $2 \%, 5 \%$ and $10 \%$ with their eyes open and closed (Hertel et al., 2006).

Testing schedule. Training tests were administered for the subjects to get used to the laboratory environment and learn how to perform joint position sense tests. Each study was conducted at least a week after the training tests. During the experiment, the room temperature was usual $\left(20-22^{\circ} \mathrm{C}\right)$. The subjects were selected randomly, females were chosen according to the duration of their menstrual cycle and ovulation day. The day for the test was set in the early follicular phase (estradiol and progesterone in blood is low); on ovulation, estradiol in blood is peak during the menstrual cycle; during luteal phase, estradiol medium, progesterone - peak during the menstrual cycle. At the beginning of the experiment, $5 \mathrm{ml}$ of venous blood sample was taken to measure the concentration of female sex hormones: estradiol and progesterone. The knee joint position sense tests were conducted.

Descriptive data is presented as means (SEM). The one-way analysis of variance (ANOVA) for repeated measures was used to determine the effect of menstrual cycle on the knee joint position sense values separately at different velocities. If significant effects were found, post hoc testing was performed, applying paired t-tests with a Bonferroni correction for multiple comparisons. Statistical significance of all tests was set at $\mathrm{p}<0.05$.

\section{RESEARCH RESULTS}

Control group values of estradiol and progesterone concentration in blood were higher during ovulation and luteal phases than in the follicular phase ( $p<0.05$; Figures 2 A, B).

Female basketball players' values of estradiol and progesterone concentration in blood were higher during ovulation and luteal phases than in the follicular phase ( $<<0.05$; Figures 3 A, B).

Females in control group performed knee joint position sense task better with an extended knee at the velocity of $2 \%$ with open eyes during the follicular phase $(\mathrm{p}<0.05$; Figure $4 \mathrm{~A})$, but at the velocity of $10 \%$ the values were better during ovulation ( $p<0.05$; Figure 4 A). Basketball players performed the same task better at the velocity of $5 \%$ during ovulation $(p<0.05$; Figure $4 A$ ), but at the velocity of $10 \%$ the values were better during the luteal phase $(p<0.05$; Figure 4 A). The females in control group performed knee joint position sense task with an extended knee at the velocity of $5 \% \mathrm{~s}$ with closed eyes better during the luteal phase $(\mathrm{p}<0.05$; Figure 4 B).

Females in control group and basketball players performed the knee joint position sense task better with a flexed knee at velocity of $10 \%$ with open eyes during ovulation $(\mathrm{p}<0.05$; Figure $5 \mathrm{~A})$. No statistical difference between control group and basketball player indices of knee joint position sense task with a flexed knee at velocity of $2 \%, 5 \%$ and $10 \%$ with closed eyes during the menstrual cycle ( $p>0.05$; Figure 5 B) was found.
Figure 1. Estimation of knee joint position sense

Note. $\mathrm{A}-$ knee joint extension till $60^{\circ}$ angle; $\mathrm{B}-$ knee joint flexion till $50^{\circ}$ angle.

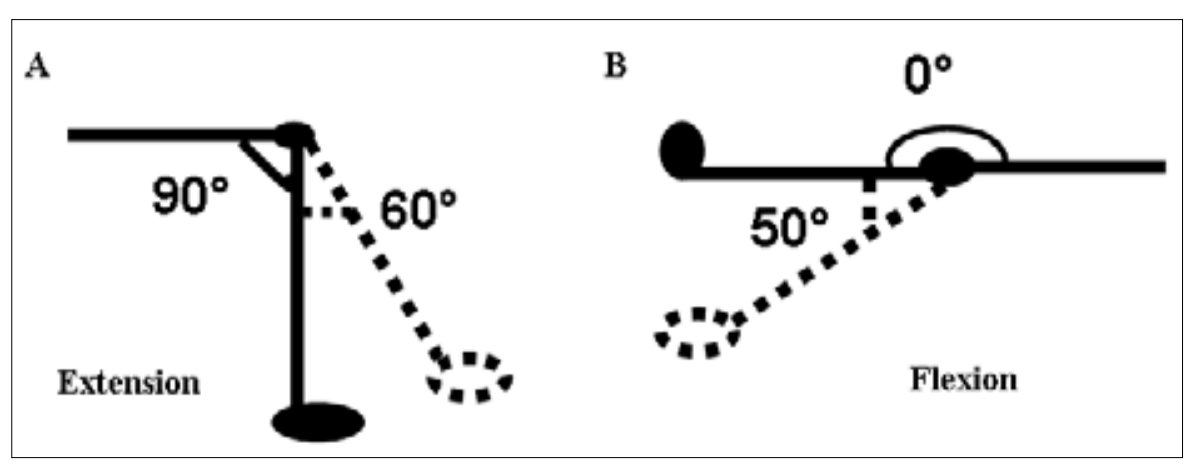



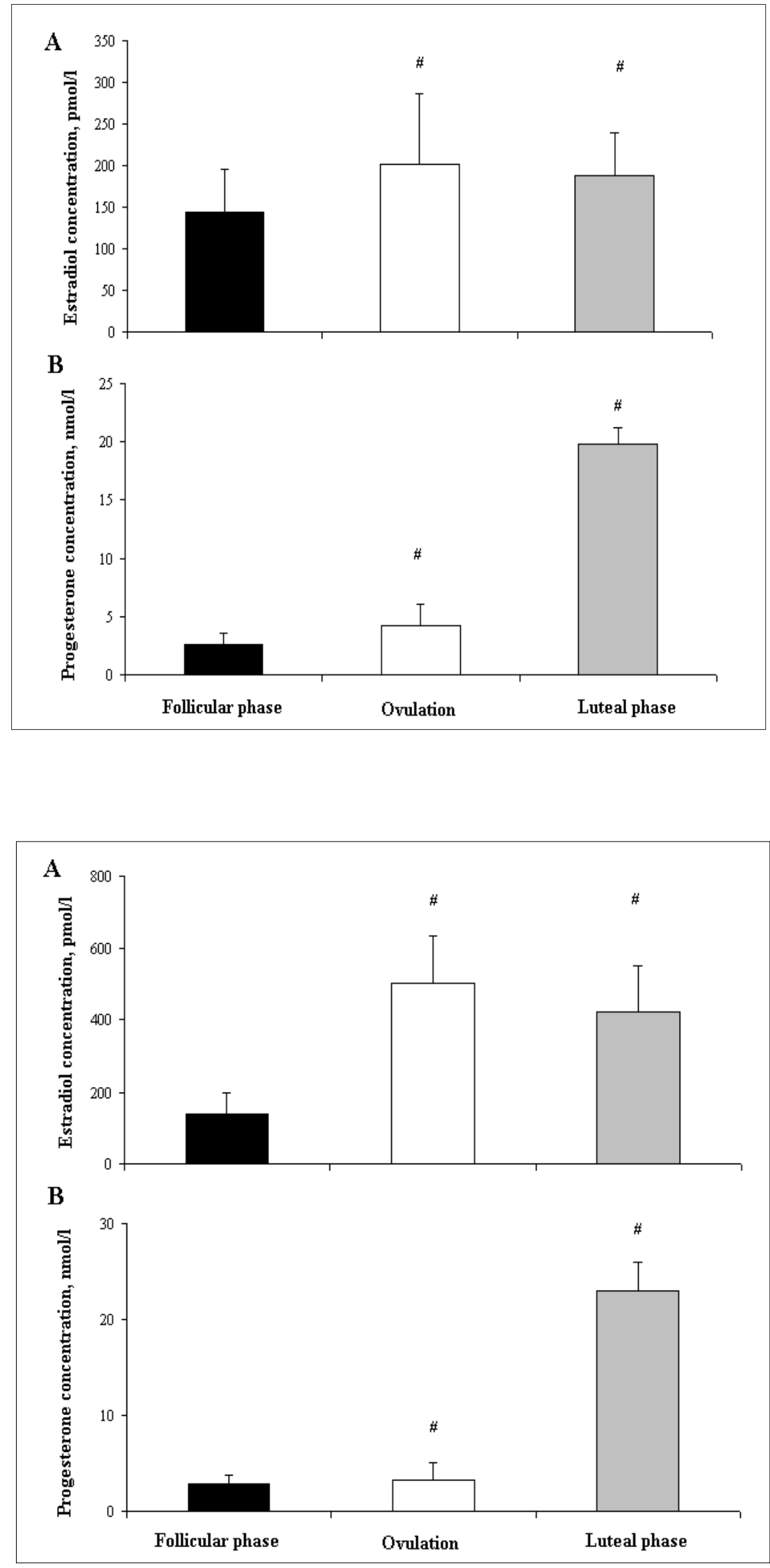

Figure 2. Control group women's estradiol (A) and progesterone (B) concentration in blood during follicular, ovulation and luteal phases

Note: $\#$ - compared to the follicular phase indices $(\mathrm{p}<0.05)$.

Figure 3. Female basketball players estradiol (A) and progesterone (B) concentration in blood during follicular, ovulation and luteal phases

Note: $\#$ - compared to the follicular phase indices $(\mathrm{p}<0.05)$. 
Figure 4. Knee joint position sense for control group and basketball players with extended knee with open (A) and closed (B) eyes during the menstrual cycle.

Note: * - compared to the ovulation phase $(\mathrm{p}<0.05)$; $\#$ - compared to the luteal phase $(\mathrm{p}<0.05)$; $\wedge$ - compared to the follicular phase $(p<0.05)$.

Figure 5. Knee joint position sense for control group and basketball players with extended knee with open (A) and closed $(B)$ eyes during the menstrual cycle

Note. * - compared to the ovulation phase $(\mathrm{p}<0.05)$; $\#$ - compared to the luteal phase $(\mathrm{p}<0.05) ; \wedge$ - compared to the follicular phase $(\mathrm{p}<0.05)$.

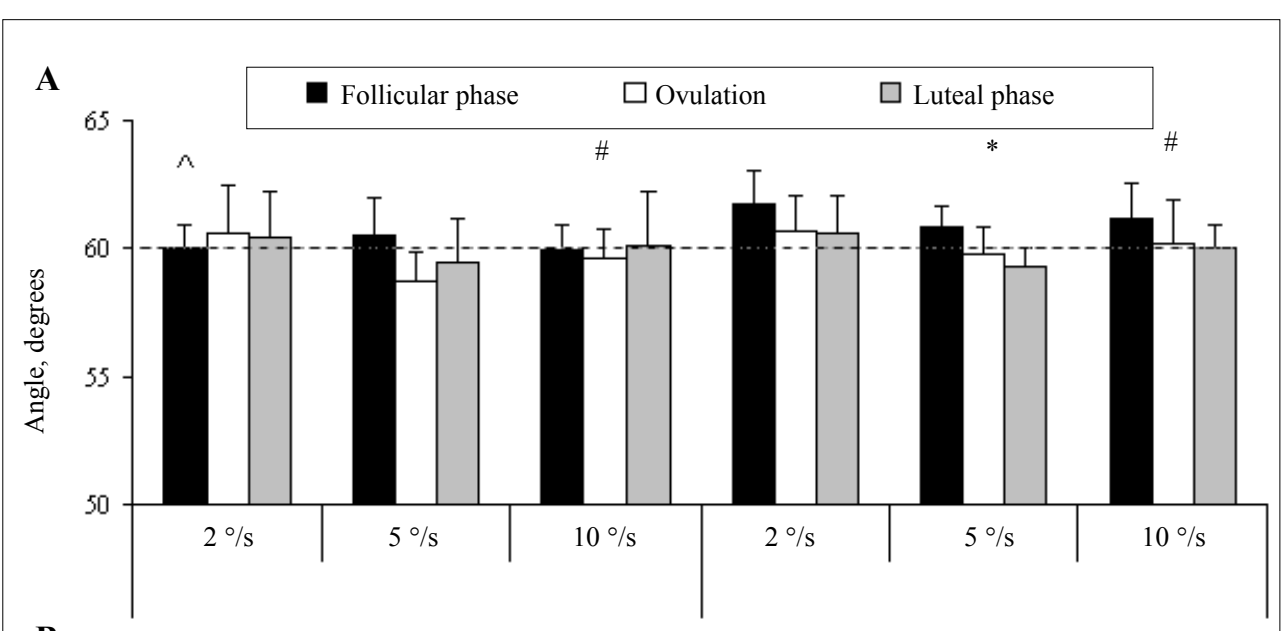

B
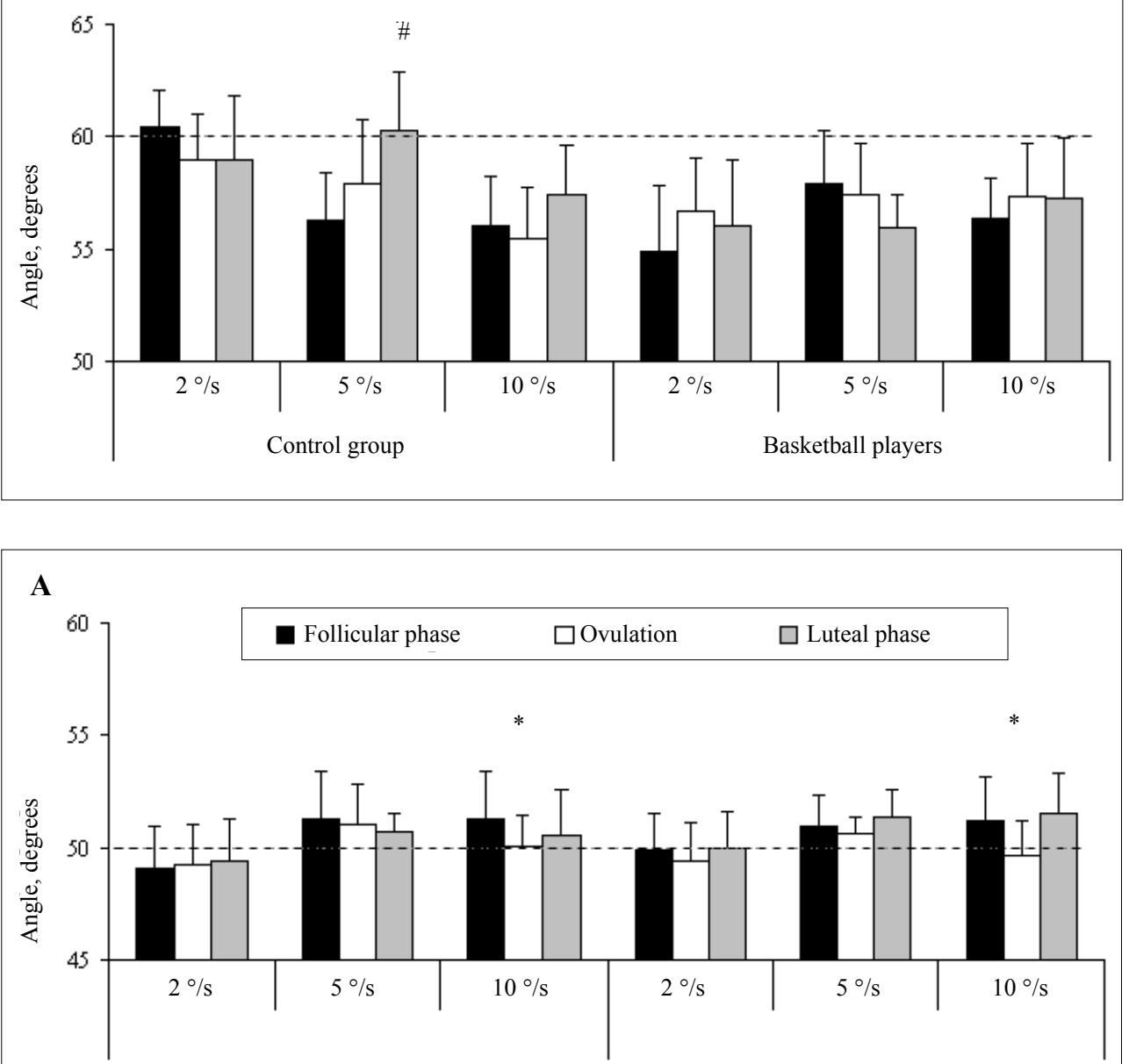

B

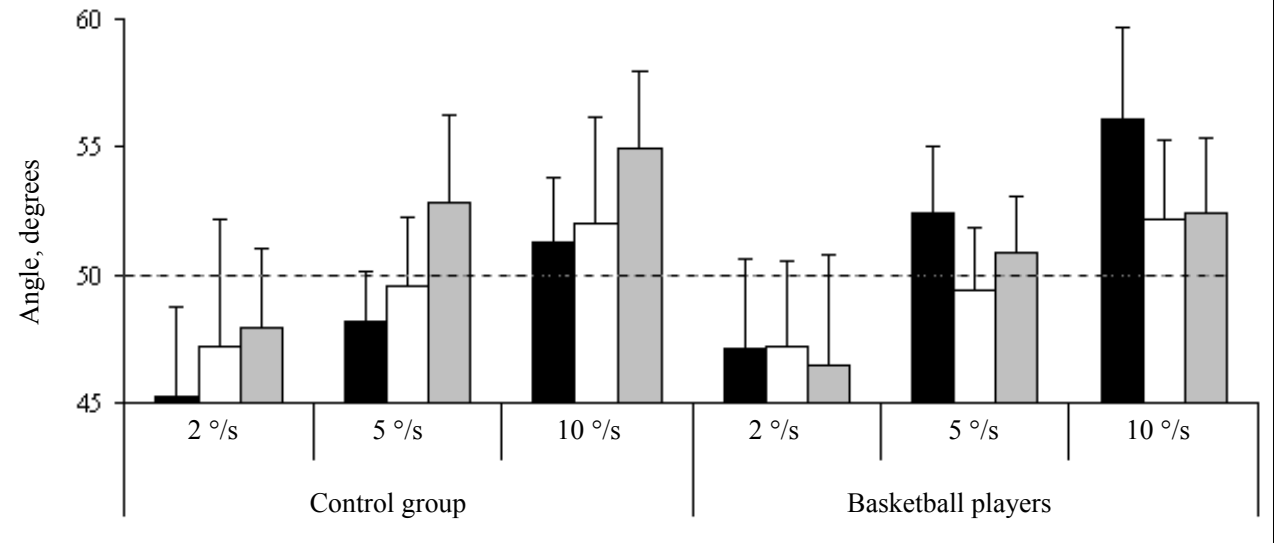




\section{DISCUSSION}

The aim of the study was to investigate the effect of increased female sex hormone concentration on movement proprioception. The present results showed that subjects were in proper menstrual cycle phase. The estradiol concentration was higher in ovulation than in follicular and luteal phases, and progesterone concentration was higher in luteal phase than in follicular phase and ovulation, when ovulation day was counted as day 14, follicular phase - day 2 for female participants. By the classical terminology of menstrual cycle phase with corresponding days of 28 -day, ovulation occurring on day 14 , follicular phase - on the $1^{\text {st }}-13^{\text {th }}$ days (Janse de Jonge, 2003). The indication of corresponding hormone concentrations on ovulation day - estradiol is high, on the day of follicular phase estradiol is low (Janse de Jonge, 2003). Knee joint proprioception indices were better during follicular and ovulation phases. When investigating female kinaesthesia indices during the menstrual cycle, no statistically significant difference between the indices of control and basketball players' groups was determined. Yet both control group women and basketball players indicated knee joint position angles when flexing and extending their leg more precisely during the luteal phase. Kinaesthesia comprises a complex of functions related to nervous and muscular systems; therefore scientists wonder whether sex hormones affect the functions through peripheral or central mechanisms. Increased level of estradiol and progesterone concentration in blood during the luteal phase affects neurotransmitters in cerebellum, which is responsible for motor functions (McEwen, 2002). The impact of changes in sex hormone concentration in blood on female bone system components, soft and connective tissues was also revealed (Wojtys et al., 2002). When estimating kinaesthetic indices, no statistically significant differences were found between movement rates. The indices varied, yet better results were recorded when performing a task at the velocities of $2 \%$ and $10 \%$. It is possible to make assumption that when position sense velocity is low $(2 \%)$ and the task is performed accurately, adaptation of CNS increases from I $\alpha$ muscle spindles and receptors in joints to peripheral signals; and when position sense velocity is high $(10 \%)$ and the task is performed accurately, CNS adaptation to peripheral signals increases from type II or dynamic muscle spindles during the movement (Brindle et al., 2009). Movement sense at the velocity of $5 \%$ encompasses information of I $\alpha$ and II type muscle spindles; thus the plane for mistakes increases.

\section{CONCLUSIONS AND PERSPECTIVES}

Knee joint proprioception indices were better in control and basketball players groups during ovulation phase.

\section{REFERENCES}

Bauman, J. E. (1981). Basal body temperature: Unreliable method of ovulation detection. Fertility and Sterility, 36 (6), 729-33.

Brindle, T. J., Mizelle, J.C., Lebiedowska, M. K., Miller, J. L., Stanhope, S. J. (2009). Visual and proprioceptive feedback improves knee joint position sense. Knee Surgery, Sport Traumatology, Arthroscopy, 17, 40-47.

Eiling, E., Bryant, A. L., Peterson, W., Murphy, A., Hohmann, E. (2007). Effect of menstrual-cycle hormone fluctuations on musculotendinous stiffness and knee joint laxity. Knee Surgery, Sport Traumatology, 15, 126-132.

Farage, M. A., Osborn, T. W., MacLean, A. B. (2008). Cognitive, sensory, and emotional changes associated with the menstrual cycle: A review. Archives of Gynecology and Obstetrics, 278, 299-307.

Friden, C., Hirschberg, A. L., Saartok, T. et al. (2003). The influence of premenstrual symptoms on postural balance and kinesthesia during the menstrual cycle. Gynecological Endocrinology, 17 (6), 433-439.
Friden, C., Hirschberg, A. L., Saartok, T., Renstrom, P. (2006). Knee joint kinaesthesia and neuromuscular coordination during three phases of the menstrual cycle in moderately active women. Knee Surgery, Sport Traumatology, 14 (4), 383-389.

Gur, R. C., Alsop, D., Glahn, D. et al. (2000). An fMRI study of sex differences in regional activation to a verbal and a spatial task. Brain and Language, 74, 157-170.

Hertel, J., Williams, N. I., Olmsted-Kramer, L. C., Leidy, H., Putukian, M. (2006). Neuromuscular performance and knee laxity do not change the menstrual cycle in female athletes. Knee Surgery, Sports Traumatology, Arthroscopy, 14, 817-822.

Janse de Jonge, X. A. K. (2003). Effects of the menstrual cycle on exercise performance. Sports Medicine, 33 (11), 833-851.

Maki, P. M., Rich, J. B., Rosenbaum, R. S. (2002). Implicit memory varies across the menstrual cycle: Estrogen effects in young women. Neuropsychology, 40, 518-529. 
McEwen, B. (2002). Estrogen actions throughout the brain. Recent Progress in Hormone Research, 57, 357-384.

Nakata, H., Yoshie, M., Miura, A., Kudo, K. (2010). Characteristics of the athletes' brain: Evidence from neurophysiology and neuroimaging. Brain Research Reviews, 62 (2), 197-211.

Osterlund, M. K., Hurd, Y. L. (2001). Estrogen receptors in the human forebrain and the relation to neuropsychiatric disorders. Progressive Neurobiology, 64 (3), 251-254.
Shen Yin-Chen, Franz, E. A. (2005). Hemispheric competition in left-handers on bimanual reaction time tasks. Journal of Motor Behavior, 37, 1, 3-9.

Shultz, S. J., Sander, T. C., Kirk, S. E., Perrin, D. H. (2005). Sex differences in knee joint laxity change across the female menstrual cycle. The Journal of Sport Medicine and Physical Fitness, 45 (4), 594-603.

Wojtys, E. M., Huston, L. J., Boyton, M. D., Spindler, K. P., Lindenfeld, T. N. (2002). The effect of the menstrual cycle on anterior cruciate ligament injuries in women as determined by hormonal level. The American Journal of Sports Medicine, 30, 182-188.

\title{
PADIDE்JUSIOS MOTERIŠKŲJŲ LYTINIŲ HORMONŲ KONCENTRACIJOS POVEIKIS JUDESIO PROPRIORECEPCIJAI
}

\author{
Laura Daniusevičiūtè ${ }^{1}$, Vitas Linonis ${ }^{1}$, Lina Barsienè $\dot{2}^{2}$ \\ Kauno technologijos universitetas ${ }^{1}$, Kaunas, Lietuva \\ Lietuvos sveikatos mokslu univesitetas, Medicinos akademija ${ }^{2}$, Kaunas, Lietuva
}

\section{SANTRAUKA}

Tyrimo pagrindimas ir hipotezé. Paskutinių metų žmoniu tyrimų rezultatai rodo hormonų poveiki sausgysliu ir raiščių dariniams. Dèl estrogenų receptorių lokalizacijos galvos smegenyse ir jų sąveikos su neurotransmiteriais (Maki et al., 2002; Friden et al., 2003; Farage et al., 2008) spejjama, kad moteriškujų lytinių hormono koncentracijos padidejimas pagerins judesio jutimo rodiklius.

Tikslas - ištirti padidejjusios moteriškujų lytinių hormonų koncentracijos poveikị judesio propriorecepcijai.

Metodai. Tiriamosios - sveikos nesportuojančios, turinčios natūralų mènesinių ciklą, fiziškai aktyvios merginos $(\mathrm{n}=15)$, kurių amžius $-19-23 \mathrm{~m}$., kūno masè $-58,2 \pm 6,1 \mathrm{~kg}$, ūgis $-168,4 \pm 5,6 \mathrm{~cm}$. Taip pat moterys krepšininkès $(\mathrm{n}=15)$, turinčios natūralų mėnesinių ciklą, kuriu amžius $-19-23 \mathrm{~m}$. , kūno masè $-78,31 \pm 2,81 \mathrm{~kg}$, ūgis $18,40 \pm 4,71 \mathrm{~cm}$. Kiekvieno eksperimento pradžioje buvo paimamas $5 \mathrm{ml}$ veninio kraujo méginys menstruacinio ciklo fazėms (folikulinei, ovuliacinei ir liuteininei) nustatyti. Tyrimo metu estradiolio ir progesterono koncentracija kraujyje nustatyta antrą dieną nuo menstruacinio ciklo pradžios (folikulinèje fazèje), 14-ą dieną nuo menstruacinio ciklo pradžios (ovuliacijos metu) ir 23-ią dieną nuo menstruacinio ciklo pradžios (liuteininèje fazèje). Kelio sąnario padèties jutimas buvo vertinamas naudojant izokinetini dinamometrą (System 3; Biodex Medical Systems, Shirley, New York, USA). Mokantis tiesti kelio sąnari, tiriamuju dešinė koja buvo sulenkiama per keli ir fiksuojama $90^{\circ}$ kampu. Tyrèjas prieš kiekvieną bandymą parodydavo, kaip tiesti koją $60^{\circ}$ kampu. Mokantis kelio sąnari lenkti, tiriamujų dešinè koja buvo ištiesiama per keli ir fiksuojama $0^{\circ}$ kampu. Tyrèjas prieš kiekvieną bandymą parodydavo, kaip lenkti koją $50^{\circ} \mathrm{kampu}$. Tiriamosios atliko tris bandymus: lenkè kojas $2 \% \mathrm{~s}, 5^{\circ} \mathrm{s}$ ir $10 \%$ greičiu atmerktomis ir užmerktomis akimis.

Rezultatai. Kontrolinès grupèje moterys užduoti geriau atliko atmerktomis akimis kelio sąnarį tiesdamos $2 \%$ greičiu folikulinès fazès metu, tačiau tą pačią užduotị atlikdamos $10 \%$ sreičiu geresnių rezultatų pasiekè ovuliacijos fazèje. Krepšininkès tą pačią užduoti geriau atliko $5 \%$ greičiu ovuliacijos fazèje, o kai greitis siekè $10 \%$ s, užduoti geriau atliko liuteininèje fazejje. Nebuvo nustatytas statistiškai patikimas skirtumas lyginant kontrolinès grupès ir krepšininkių kelio sąnario lenkimo užduoties rodiklius užmerktomis akimis, kai kelio sąnario lenkimo greitis $2 \%$, $5 \%$ ir $10 \%$ s menstruacinio ciklo metu.

Aptarimas ir išvados. Kontrolinès grupès krepšininkiu kelio sąnario propriorecepcijos rodikliai buvo geresni ovuliacijos fazèje.

Raktažodžiai: kelio sąnario propriorecepcija, folikulinė fazè, ovuliacija, liuteininė fazè.

Gauta 2012 m. birželio 21 d.

Received on June 21, 2012

Priimta $2012 \mathrm{~m}$. rugsëjo $7 \mathrm{~d}$.

Accepted on September 7, 2012
Corresponding author Laura Daniusevičiūtè Lithuanian Academy of Physical Education Sporto str. 6, LT-44221 Kaunas

Lithuania

Tel +37060065490

E-mail lauruka@yahoo.com 